dr inż. Maria Teresa Markiewicz ${ }^{1}$

Przyjęty/Accepted/Принята: 24.11.2014;

Zrecenzowany/Reviewed/Рецензирована: 10.09.2015;

Opublikowany/Published/Опубликована: 31.12.2015;

\title{
Analiza wybranych dokumentów planistycznych pod względem zagrożenia awariami przemysłowymi na przykładzie Poznania
}

\author{
An Analysis of Selected Planning Documents in Context of Hazards Presented by \\ Industrial Accidents: Case Study Involving Poznań
}

\begin{abstract}
Анализ выбранных документов планирования относительно угрозы промышленных аварий на примере г. Познань
\end{abstract}

\begin{abstract}
ABSTRAKT
Cel: Ocena dokumentów planistycznych z obszaru Poznania pod względem zapisów dotyczących zagrożenia poważnymi awariami przemysłowymi.

Wprowadzenie: Zakłady przemysłowe, w szczególności te zaliczane do zakładów o dużym ryzyku (ZDR) lub zakładów o zwiększonym ryzyku wystąpienia awarii przemysłowej (ZZR), w przypadku wystąpienia awarii mogą stanowić zagrożenie dla środowiska oraz mieszkańców i ich mienia. Planowanie przestrzenne jest jednym z narzędzi pozwalających na zmniejszanie tego zagrożenia poprzez odpowiednie zagospodarowanie terenów wokół takich zakładów, co powinno być odzwierciedlone w zapisach dokumentów planistycznych. Na terenie Poznania występuje 5 zakładów ZZR. Zakładów ZDR nie ma. Studium dla Poznania uchwalono w 1999 r. i uaktualniano je w latach 2008 i 2014. Tylko trzy spośród pięciu zakładów ZZR z Poznania objęte są miejscowymi planami.

Metodologia: Wykonywanie pracy przebiegało w następujących etapach: określenie lokalizacji zakładów ZZR na terenie Poznania, przyporządkowanie poszczególnym zakładom miejscowych planów, przeprowadzenie analizy zapisów dostępnych dokumentów planistycznych. W analizach wykorzystano metodę opisową.

Wnioski: Informacja o lokalizacji zakładu ZZR i zagrożeniu poważną awarią znajduje się tylko w jednym na trzy analizowane zestawy dokumentów planistycznych. Można to próbować wyjaśnić tym, że wszystkie analizowane miejscowe plany zostały uchwalone przed wprowadzeniem obowiązku ich opiniowania pod względem zagrożenia poważnymi awariami przemysłowymi i tylko jeden z rozważanych zakładów został zgłoszony jako ZZR przed uchwaleniem planu. Optymizmem nastrajają wyraźne zapisy - wprowadzone do aktualizacji studium z 2014 r. - o istniejących na terenie Poznania zakładach ZZR, strefach zagrożeń wokół nich i możliwościach wystąpienia poważnej awarii przemysłowej. Nie zaobserwowano, aby pojęcie odległości bezpiecznej było używane w praktyce planistycznej. W artykule przedstawiono regulacje prawne obowiązujące na dzień 15 września 2015 r. oraz propozycje zmian związanych z koniecznością dostosowania przepisów obowiązujących w Polsce do wymagań nowej Dyrektywy Seveso III, która weszła w życie 1 czerwca 2015 r. Zdaniem autorki warto zastanowić nad rozszerzeniem projektu Rozporządzenia Ministra Środowiska w sprawie ustalania bezpiecznej odległości przy lokalizacji zakładów stwarzających zagrożenie wystąpienia poważnej awarii o referencyjny model matematyczny do wyznaczania stref zagrożenia.
\end{abstract}

Słowa kluczowe: zagospodarowanie przestrzenne, Dyrektywa Seveso, poważna awaria przemysłowa Typ artykułu: $z$ praktyki dla praktyki

\section{ABSTRACT}

Aim: The evaluation of planning documents for Poznań area, in context of recording hazards presented by major industrial accidents. Introduction: In case of an accident, industrial plants, particularly those categorised as high risk (higher category), or plants with an elevated industrial accident risk (lesser category), may be a source of danger to the environment, inhabitants of the area and their property. Regional development planning provides a facility to mitigate such a risk through suitable planning of developments in the immediate vicinity of industrial plants and this information should be reflected in planning documents. There are five plants with an elevated industrial accident risk potential located in Poznań. There are no plants categorised as high risk plants in the area. A study covering the Poznań area was adopted in 1999 and revised in 2008, and in 2014. Only three out of five plants with an elevated industrial accident risk potential in Poznań are encapsulated by local management plans.

\footnotetext{
Politechnika Warszawska / Warsaw University of Technology; maria.markiewicz@is.pw.edu.pl;
} 
Methodology: Work was performed in the following stages; identification of plant location in Poznań, assignment of area management plans to the plants and analysis of provisions within accessible planning documents. Descriptive methods were used in the analysis.

Conclusion: Information about the location of plants with an elevated risk of an industrial accident and danger of a serious accident were found in one of the three analysed planning documents. This may be explained by the fact that all analysed local management plans were adopted before the introduction of regulatory requirements to incorporate an opinion about dangers of a serious industrial accidents. Consequently only one plant under scrutiny was categorised as a plant with an elevated risk of an industrial accident before adoption of the plan. A degree of optimism is generated by clear records, revealing the existence of industrial plants with an elevated risk of industrial accidents in the Poznań region, identification of the danger zone surrounding the plants and potential for a serious industrial accident, which was introduced into the study update of 2014. There was no evidence to show that that the concept of 'safe distance' was applied during planning. The article identified legal requirements effective from 15 September 2015, as well as proposed changes associated with the need to align Polish regulations to requirements of the new Seveso III Directive, which came into force on 1 June 2015 . It may be pertinent to consider broadening draft regulations from the Minister for the Environment, dealing with the establishment of safe distances for the location of plants with a risk of a major accident, with the use of a mathematical reference model to identify danger zones.

Keywords: regional development planning, Seveso Directive, major industrial accident

Type of article: best practice in action

\section{АННОТАЦИЯ}

Цель: Оценка документов планирования на примере города Познань с точки зрения положений, касающихся угрозы возникновения серьёзных промышленных аварий.

Введение: Промышленные предприятия, в частности те, которые относятся к предприятиям большого риска (ZDR) или предприятиям повышенного риска возникновения промышленной аварии (ZZR), в случае возникновения аварии могут представлять угрозу для окружающей среды, жителей и имущества. Пространственное планирование является одним из инструментов, позволяющих снизить эту угрозу путем соответствующего использования районов вокруг предприятий, что должно быть отражено в документах планирования. На территории г. Познань находится пять предприятий повышенного риска возникновения промышленной аварии (ZZR). Предприятий большого риска (ZDR) нет. Анализ для г. Познань был принят в 1999 году и обновлен в 2008 и 2014 годах. Только 3 из 5 предприятий повышенного риска возникновения промышленной аварии в г. Познань взяты во внимание в местных планах.

Методология: Работа выполнялась следующими этапами: определение местоположения предприятий повышенного риска возникновения промышленной аварии (ZZR) на территории г. Познань, принадлежность местных планов к отдельным предприятиям, проведение анализа записей имеющихся документов планирования. В анализах использован описательный метод. Выводы: Информация о месте нахождения предприятия повышенного риска возникновения промышленной аварии (ZZR) и угрозе крупной аварии присутствует лишь в одном из трех наборов анализируемых документов планирования. Это можно объяснить тем, что все анализируемые местные планы были приняты до введения их обязательной оценки касающейся угрозы возникновения крупных промышленных аварий, и только одно из рассматриваемых предприятий было определено как ZZR до принятия плана. Оптимистическими являются четкие записи о существующих предприятиях на территории г. Познань ZZR, зонах угрозы вокруг них и возможной крупной промышленной аварии, внедрённые до обновления анализа 2014 года.

Не замечено использования понятия безопасное расстояние в практике планирования. В статье представлены правовые нормы, действующие на день 15 сентября 2015 года, а также предложения изменений, связанные с необходимостью адаптации правил в Польше с требованиями новой директивы Севезо III, которая вступила в силу 1 июня 2015 года. Возможно было бы целесообразно рассмотреть вопрос расширения проекта Распоряжения Министра охраны окружающей среды относительно определения безопасного расстояния вокруг предприятий, представляющего угрозу крупной аварии, реферативной математической моделью для определения опасных зон.

Ключевые слова: пространственное планирование, Севезо, серьёзная промышленная авария

Вид статьи: с практики для практики

\section{Wprowadzenie}

Zakłady przemysłowe w przypadku wystąpienia awarii mogą stanowić zagrożenie dla środowiska oraz mieszkańców i ich mienia. $Z$ tego względu niezwykle istotne jest podejmowanie działań, które prowadzą do zapobiegania wystąpieniu takich sytuacji oraz minimalizacji ich ewentualnych skutków. Planowanie przestrzenne jest jednym z narzędzi pozwalających na realizację tego celu. Dzieje się to poprzez odpowiednią lokalizację zakładów przemysłowych, jak również dzięki niedopuszczeniu do powstawania zabudowy mieszkaniowej oraz użyteczności publicznej w okolicy już istniejącego zakładu.
Głównymi dokumentami planistycznymi na poziomie gminy są: studium uwarunkowań i kierunków zagospodarowania przestrzennego gminy oraz miejscowe plany zagospodarowania przestrzennego. Studium określa politykę przestrzenną gminy. Zakres ustaleń studium musi być zgodny z art. 10 Ustawy z dnia 27 marca 2003 r. o planowaniu i zagospodarowaniu przestrzennym (Dz.U. z 2015 r., poz. 774) [1] i Rozporządzeniem Ministra Infrastruktury z dnia 28 kwietnia 2004 r. w sprawie wymaganego zakresu projektu studium uwarunkowań i kierunków zagospodarowania przestrzennego (Dz.U. z 2004 r. nr 118, poz. 1233) [2]. Na podstawie studium, przy uwzględnieniu zawartych w nim wytycznych, opracowywane są miejscowe plany. Zakres miejscowych planów określa art. 15 Ustawy z dnia 
27 marca 2003 r. o planowaniu i zagospodarowaniu przestrzennym [1] i Rozporządzenie Ministra Infrastruktury z dnia 26 sierpnia 2003 r. w sprawie wymaganego zakresu projektu miejscowego planu zagospodarowania przestrzennego (Dz.U. z 2003 r. nr 164, poz. 1587) [3].

W dokumentach planistycznych, a także w prognozach oddziaływania na środowisko - sporządzanych obowiązkowo do tych dokumentów na mocy art. 46 Ustawy z dnia 3 października 2008 r. o udostępnianiu informacji o środowisku i jego ochronie, udziale społeczeństwa w ochronie środowiska oraz o ocenach oddziaływania na środowisko (Dz.U. z 2013, poz. 1235) [4] - należy uwzględniać zagrożenie wynikające $\mathrm{z}$ możliwych poważnych awarii przemysłowych.

Zgodnie z definicją zawartą w ustawie $\mathrm{z}$ dnia 27 kwietnia 2001 r. Prawo ochrony środowiska (Dz.U. z 2015, poz. 933) [5] poważna awaria to „zdarzenie, w szczególności emisja, pożar lub eksplozja, powstałe w trakcie procesu przemysłowego, magazynowania lub transportu, w których występuje jedna lub więcej niebezpiecznych substancji, prowadzące do natychmiastowego powstania zagrożenia życia lub zdrowia ludzi lub środowiska, lub powstania takiego zagrożenia z opóźnieniem" [5, s. 7]. Gdy zdarzenie takie ma miejsce w zakładzie - rozumianym zgodnie z Ustawą jako „jedna lub kilka instalacji wraz z terenem, do którego prowadzący instalacje posiada tytuł prawny, oraz znajdujące się na nim urządzenia" [5, s. 14] - mamy wtedy do czynienia z poważną awarią przemysłową.

W publikacji przedstawiono ocenę wybranych dokumentów planistycznych dla Poznania pod względem zapisów związanych z zagrożeniem poważnymi awariami przemysłowymi. Analizy studium uwarunkowań i kierunków zagospodarowania przestrzennego Poznania oraz wybranych miejscowych planów zagospodarowania przestrzennego wraz z ich prognozami oddziaływania na środowisko zostały przeprowadzone w ramach pracy statutowej w Katedrze Ochrony i Kształtowania Środowiska na Wydziale Inżynierii Środowiska Politechniki Warszawskiej [6]. Realizacja pracy wymagała: określenia miejsc lokalizacji zakładów zagrożonych ryzykiem poważnej awarii przemysłowej na obszarze Poznania, przyporządkowania tym zakładom odpowiednich miejscowych planów i przeprowadzenia analizy zapisów tych dokumentów. Wykorzystano metodę opisową. Studium i miejscowe plany były zgromadzone na stronie internetowej Miejskiej Pracowni Urbanistycznej w Poznaniu, a prognozy oddziaływania na środowisko pracownia udostępniła na pisemną prośbę autorki.

\section{Najważniejsze akty prawa międzynarodowego i Unii Europejskiej dotyczące uwzględniania zagrożenia awariami przemysłowymi w zagospodarowaniu przestrzennym}

Wśród przepisów międzynarodowych najważniejsze są: Konwencja Europejskiej Komisji Gospodarczej Organizacji Narodów Zjednoczonych (EKG ONZ) w sprawie transgranicznych skutków awarii przemysłowych sporządzona w Helsinkach dnia 18 marca 1992 r., zwana Konwencją awaryjną [7], Konwencja EKG ONZ o ocenach oddziaływania na środowisko w kontekście transgranicznym sporządzona w Espoo dnia 25 lutego 1991 r. [8] oraz Konwencja EKG ONZ o dostępie do informacji, udziale społeczeństwa w podejmowaniu decyzji oraz dostępie do sprawiedliwości w sprawach dotyczących środowiska, podpisana w Aarhus 25 czerwca 1998 roku [9].

Wśród najważniejszych przepisów Unii Europejskiej należy wymienić: Dyrektywę Parlamentu Europejskiego i Rady 2012/18/UE z dnia 4 lipca 2012 r. w sprawie kontroli zagrożeń poważnymi awariami związanymi z substancjami niebezpiecznymi czyli tzw. Dyrektywę Seveso III [10], Dyrektywę Rady 2003/35/WE z dnia 26 maja 2003 r. przewidującą udział społeczeństwa w odniesieniu do sporządzania niektórych planów i programów w zakresie środowiska [11] oraz zmieniające w odniesieniu do udziału społeczeństwa i dostępu do wymiaru sprawiedliwości Dyrektywy Rady 85/337/EWG [12] i 96/61/WE [13] oraz Dyrektywę 2001/42/WE Parlamentu Europejskiego i Rady z dnia 27 czerwca 2001 r. w sprawie oceny wpływu niektórych planów i programów na środowisko czyli tzw. Dyrektywę SOOŚ [14].

Należy zaznaczyć, że Dyrektywa Seveso III zastąpiła obowiązującą do 31 maja 2015 r. Dyrektywę Rady 96/82/ WE z dnia 9 grudnia 1996 r. dotyczącą zarządzania poważnymi awariami przemysłowymi z udziałem substancji niebezpiecznych czyli tzw. Dyrektywę Seveso II [15] i Dyrektywę Parlamentu Europejskiego i Rady 2003/105/WE z dnia 16 grudnia 2003 r. nowelizującą zapisy Dyrektywy Seveso II [16]. Głównym celem nowej Dyrektywy było podniesienie poziomu ochrony przed awariami w sektorze gospodarującym substancjami niebezpiecznymi. Kluczowym powodem przyjęcia nowej regulacji była konieczność uwzględnienia zmian dotyczących klasyfikowania substancji i mieszanin chemicznych. Nowy system klasyfikacji substancji niebezpiecznych wprowadzony został Rozporządzeniem Parlamentu Europejskiego i Rady (WE) nr 1272/2008 z dnia 16 grudnia 2008 r. w sprawie klasyfikacji, oznakowania i pakowania substancji i mieszanin, zmieniając i uchylając Dyrektywy 67/548/EWG] i 1999/45/WE oraz zmieniając rozporządzenie (WE) $\mathrm{nr}$ 1907/2006 (Dz.Urz. UE L 353 z 31.12.2008) (Rozporządzenie CLP) [17].

W Dyrektywie Seveso III, oprócz zmian związanych $\mathrm{z}$ dostosowaniem kryteriów kwalifikacyjnych do Rozporządzenia CLP, konieczne było uwzględnienie aspektów określonych w Konwencji dotyczącej dostępu do informacji, udziału społeczeństwa w podejmowaniu decyzji oraz dostępu do wymiaru sprawiedliwości w sprawach dotyczących środowiska [9], a także dotyczących zagadnień związanych z zagospodarowaniem przestrzennym czy kontrolą instalacji. Termin transpozycji Dyrektywy Seveso III upłynął 31 maja 2015 r. Procedura ta nie została zakończona.

Warto zauważyć, że szczegółowe omówienie zapisów Dyrektywy Seveso III ze wskazaniem wprowadzonych zmian w stosunku do zapisów Dyrektywy Seveso II można znaleźć na przykład na stronie internetowej CIOP [18], z której pochodzi następujący cytat, odnoszący się do sposobu ujęcia w Dyrektywie Seveso III 
kwestii planistycznych: „Duży nacisk został położony na zagadnienia związane $\mathrm{z}$ zagospodarowaniem przestrzennym, m.in. kontrolowaniem lokalizacji nowych zakładów, zmianach, które powinny zostać wprowadzone $\mathrm{w}$ istniejących zakładach oraz $\mathrm{w}$ ich otoczeniu, $\mathrm{z}$ uwzględnieniem tzw. bezpiecznych odległości lub wprowadzeniem dodatkowych środków technicznych, a także konieczności bliższej współpracy między różnymi organami, w tym również współpracy między państwami członkowskimi a Komisją".

\section{Regulacje prawne dotyczące uwzględniania zagrożenia poważnymi awariami przemysłowymi w zagospodarowaniu przestrzennym w Polsce}

W artykule przedstawiono regulacje prawne obowiązujące w Polsce na dzień 15 września 2015 r., które są związane z tematyką pracy oraz propozycje zmian prawa krajowego, obecnie realizowane, które dostosowują je do postanowień Dyrektywy Seveso III.

W prawodawstwie polskim zagadnienia dotyczące poważnych awarii przemysłowych w nawiązaniu do zagospodarowania przestrzennego zawarte zostały przede wszystkim w Ustawie z dnia 27 kwietnia 2001 r. Prawo ochrony środowiska (Dz.U. z 2015 r., poz. 933) [5], Ustawie z dnia 27 marca 2003 r. o planowaniu i zagospodarowaniu przestrzennym (Dz.U. z 2015 r., poz. 774) [1], Ustawie z dnia 3 października 2008 r. o udostępnianiu informacji o środowisku i jego ochronie, udziale społeczeństwa w ochronie środowiska oraz o ocenach oddziaływania na środowisko (Dz.U. z 2013 r., poz. 1235) [4], Ustawie z dnia 24 sierpnia 1991 r. o Państwowej Straży Pożarnej (Dz.U. z 2015 r., poz. 881) [19], Ustawie z dnia 20 lipca 1991 r. o Inspekcji Ochrony Środowiska (Dz.U. z 2015 r., poz. 1223) [20] oraz w szeregu akt wykonawczych wydanych na podstawie tych ustaw, które wymieniono w dalszej części artykułu.

Zgodnie $\mathrm{z}$ art. 73 Ustawy Prawo ochrony środowiska [5] lokalizacja zakładów stwarzających zagrożenie wystąpienia poważnej awarii powinna uwzględniać bezpieczne odległości od: budynków mieszkalnych oraz użyteczności publicznej, obszarów chronionych przepisami Ustawy z dnia 16 kwietnia 2004 r. o ochronie przyrody (Dz.U. z 2015 r., poz. 1045) [21] oraz Ustawy z dnia 18 lipca 2001 r. Prawo wodne (Dz.U. z 2015 r., poz. 469) [22], upraw wieloletnich, dróg krajowych i linii kolejowych o znaczeniu państwowym. Lokalizowanie tych zakładów powinno odbywać się także w bezpiecznych odległościach od istniejących zakładów, których działalność może być powodem wystąpienia poważnej awarii. Dla istniejących zakładów, które zlokalizowane są bez zachowania bezpiecznych odległości, odpowiednie organy Inspekcji Ochrony Środowiska, po uzyskaniu opinii właściwego organu Państwowej Straży Pożarnej, mogą nakazać wprowadzenie dodatkowych rozwiązań technicznych w celu poprawy bezpieczeństwa ludzi.

Można zauważyć, że regulacje prawne nie podają ani definicji „odległości bezpiecznej” ani referencyjnej metodyki jej wyznaczania. Próba definicji tego terminu pojawia się w opracowaniu wydanym przez Główny Inspektorat Ochrony Środowiska o charakterze wytycznych, a więc nieobligatoryjnym pt. Metodologia określania bezpiecznych lokalizacji zakładów mogacych powodować poważne awarie [23] i brzmi: „jest to odległość pomiędzy obiektami stwarzającymi zagrożenie poważną awarią a obszarami wrażliwymi (np. osiedla mieszkaniowe, urzędy, obszary przyrodniczo chronione)" [23 s. 5].

Zgodnie z art. 248 Ustawy Prawo ochrony środowiska [5] zakłady stwarzające zagrożenie poważną awarią przemysłową, w zależności od rodzaju, kategorii i ilości substancji niebezpiecznej występującej w zakładzie, uznaje się za zakłady o dużym ryzyku wystąpienia awarii przemysłowej (ZDR) albo za zakłady o zwiększonym ryzyku wystąpienia awarii przemysłowej (ZZR). Rodzaje i ilości substancji niebezpiecznych, decydujące o zaliczeniu zakładu przemysłowego do któregoś z wymienionych rodzajów, określone są w Rozporządzeniu Ministra Gospodarki z dnia 9 kwietnia 2002 r. w sprawie rodzajów i ilości substancji niebezpiecznych, których znajdowanie się w zakładzie decyduje o zaliczeniu go do zakładu o zwiększonym ryzyku albo zakładu o dużym ryzyku wystąpienia poważnej awarii przemysłowej (Dz.U. z 2002 r. nr 58, poz. 535) [24].

Warto dodać, że jako potencjalnych sprawców poważnych awarii przemysłowych w raportach GIOŚ wymienia się również zakłady pozostałe, których działalność może spowodować awarię w rozumieniu przepisów określonych w Rozporządzeniu Ministra Środowiska z dnia 30 grudnia 2002 r. w sprawie poważnych awarii objętych obowiązkiem zgłoszenia do Głównego Inspektora Ochrony Środowiska (Dz.U. z 2002 r. nr 5, poz. 58) [25]. Kryterium klasyfikacji do tej grupy zakładów stanowi występowanie na terenie zakładu substancji niebezpiecznych w ilości co najmniej 5\% ilości, której posiadanie kwalifikuje zakład do grupy zakładów ZDR [26].

Zgodnie $\mathrm{z}$ art. 250 Ustawy Prawo ochrony środowiska [5] w celu oceny bezpieczeństwa w zakładach ZDR i ZZR sporządzane są specjalistyczne opracowania. Dla ZDR są to: program zapobiegania poważnym awariom przemysłowym, system bezpieczeństwa, raport o bezpieczeństwie oraz wewnętrzny i zewnętrzny plan operacyjno-ratowniczy. Dla ZZR wymagane jest sporządzenie programu zapobiegania awariom. Zawartość raportu o bezpieczeństwie i planów operacyjno-ratowniczych określają odpowiednio: Rozporządzenie Ministra Gospodarki, Pracy i Polityki Społecznej z dnia 29 maja 2003 r. w sprawie wymagań, jakim powinien odpowiadać raport o bezpieczeństwie zakładu o dużym ryzyku (Dz.U. z 2003 r. nr 104, poz. 970) [27] i Rozporządzenie Ministra Gospodarki, Pracy i Polityki Społecznej z dnia 17 lipca 2003 r. w sprawie wymagań, jakim powinny odpowiadać plany operacyjno-ratownicze (Dz.U. z 2003 r. nr 131, poz. 1219) [28].

Warto podkreślić, że informacje zawarte w tych opracowaniach mogą być bardzo pomocne przy sporządzaniu dokumentów planistycznych dotyczących zagospodarowania terenów wokół zakładów ZDR i ZZR i wyznaczaniu odległości bezpiecznych. 
Ustawa Prawo ochrony środowiska [5] w art. 73 wprowadza zakaz lokalizowania nowych zakładów stwarzających zagrożenie dla życia lub zdrowia mieszkańców na terenach zwartej zabudowy wsi oraz w granicach administracyjnych miast, $\mathrm{z}$ wyjątkiem terenów przeznaczonych w miejscowych planach zagospodarowania przestrzennego pod działalność produkcyjną, składowanie i magazynowanie. Rozbudowa istniejących zakładów przemysłowych stwarzających zagrożenie wystąpienia poważnych awarii jest dopuszczalna na tych terenach, jeżeli przyczyni się do ograniczenia tego zagrożenia.

Art. 267 Ustawy Prawo ochrony środowiska [5] nakłada na Komendanta Wojewódzkiego Państwowej Straży Pożarnej obowiązek podania do publicznej wiadomości informacji o rejestrze substancji niebezpiecznych, grupach zakładów ZDR lub ZZR, które - zlokalizowane w niewielkiej odległości od siebie - mogą powodować zwiększenie ryzyka wystąpienia awarii przemysłowej oraz jej ewentualnych skutków, raportach bezpieczeństwa lub ich zmianach, zewnętrznych planach operacyjnych lub ich zmianach oraz instrukcjach postępowania dla mieszkańców w przypadku wystąpienia awarii. Zakres tych informacji określa Rozporządzenie Ministra Środowiska z dnia 4 czerwca 2002 r. w sprawie szczegółowego zakresu informacji wymaganych do podania do publicznej wiadomości przez Komendanta Wojewódzkiego Państwowej Straży Pożarnej (Dz.U. 2002 r. nr 78, poz. 712) [29].

Zgodnie z Ustawą z dnia 27 marca 2003 r. o planowaniu i zagospodarowaniu przestrzennym [1] w dokumentach planistycznych opracowywanych na poziomie gminy, jakimi są studia uwarunkowań i kierunków zagospodarowania przestrzennego gminy oraz miejscowe plany zagospodarowania przestrzennego, należy uwzględnić problematykę zagrożenia poważnymi awariami przemysłowymi. Zgodnie z art. 11 ww. Ustawy, po podjęciu uchwały o przystąpieniu do sporządzenia studium uwarunkowań i kierunków zagospodarowania przestrzennego gminy w zakresie lokalizacji ZZR oraz ZDR, a także zabudowy mieszkaniowej i przestrzeni publicznych w sąsiedztwie istniejących zakładów, konieczne jest jego zaopiniowanie przez właściwy organ Państwowej Straży Pożarnej i Wojewódzkiego Inspektora Ochrony Środowiska. W art. 11 Ustawa nakłada obowiązek takiego samego zaopiniowania w stosunku do projektów miejscowych planów zagospodarowania przestrzennego. W art. 23 Ustawy organy te zostały uznane jako organy właściwe do współpracy przy sporządzaniu odpowiednio: projektu studium albo miejscowego planu polegającej na wyrażeniu opinii, składaniu wniosków oraz udostępniania informacji. Oznacza to, że są one źródłem informacji o możliwościach wystąpienia sytuacji wymagających określenia bezpiecznych odległości w otoczeniu zakładów ZDR lub ZZR. Przepisy te wprowadzono do Ustawy dopiero w $2010 \mathrm{r}$.

Warto zwrócić uwagę, że obowiązek opiniowania opracowań planistycznych nie obejmuje zakładów określanych terminem „zakłady pozostałe”, będących potencjalnymi sprawcami poważnych awarii przemysłowych poza ZZR i ZDR.
Dla sporządzanych dokumentów planistycznych ważna jest Ustawa z dnia 3 października 2008 r. o udostępnianiu informacji o środowisku i jego ochronie, udziale społeczeństwa w ochronie środowiska oraz o ocenach oddziaływania na środowisko [4]. Ustawa wymienia dokumenty wymagające przeprowadzenia strategicznej oceny oddziaływania na środowisko, a także określa zakres prognozy oddziaływania na środowisko, sposób opiniowania i przyjęcia dokumentu oraz udział społeczeństwa w całej procedurze. Zgodnie $\mathrm{z}$ art. 51 tej Ustawy prognoza powinna m.in. określać, analizować i oceniać przewidywane znaczące oddziaływania na środowisko, jak również przedstawiać rozwiązania mające na celu zapobieganie, ograniczanie i kompensację przyrodniczą negatywnych oddziaływań na środowisko. Przed rokiem 2008 obowiązek sporządzania prognozy wynikał z Ustawy Prawo ochrony środowiska [5], a sposób jej wykonania określało Rozporządzenie Ministra Ochrony Środowiska, Zasobów Naturalnych i Leśnictwa z dnia 29 marca 1995 r. w sprawie określenia wymagań, jakim powinna odpowiadać prognoza skutków wpływu ustaleń miejscowego planu zagospodarowania przestrzennego na środowisko przyrodnicze (Dz.U. 1995 r. nr 29, poz. 150) [30].

Do kontroli zakładów w zakresie poważnych awarii upoważnione są organy Inspekcji Ochrony Środowiska i Państwowej Straży Pożarnej. Kontrolę podmiotów korzystających ze środowiska w zakresie przeciwdziałania poważnym awariom oraz sprawowania nadzoru nad usuwaniem ich skutków, jako jedno z zadań przypisanych Inspekcji Ochrony Środowiska wymienia art. 2 Ustawy Inspekcja Ochrony Środowiska [20].

Zasady i tryb przeprowadzania kontroli zakładów, objętych przepisami w zakresie poważnych awarii wykonywanych przez właściwe organy Państwowej Straży Pożarnej, regulują art. 269 Ustawy Prawo ochrony środowiska [5] i art. 23 Ustawy o Państwowej Straży Pożarnej [19]. Wydane Rozporządzenie Ministra Spraw Wewnętrznych i Administracji z dnia 24 października 2005 r. w sprawie czynności kontrolno-rozpoznawczych przeprowadzanych przez Państwową Straż Pożarną (Dz.U. nr 225, poz. 1934) [31] ma umożliwić właściwą realizację tych czynności oraz ich dokumentację.

We wspomnianej Metodologii określania bezpiecznych lokalizacji zakładów mogacych powodować poważne awarie [23], [32] przedstawiona została metoda wyznaczania bezpiecznych odległości od zakładów ZZR lub ZDR, gdy planowana jest budowa nowego obiektu przemysłowego, przebudowa, rozbudowa lub modernizacja istniejącego obiektu tego rodzaju, a także gdy istnieje zamiar zbliżenia obiektów mieszkalnych, usługowych lub użyteczności publicznej do istniejących obiektów ZZR lub ZDR. Odległości bezpieczne, podane w formie tabelarycznej, opracowane zostały w oparciu o doświadczenie użytkowników instalacji, opinie ekspertów oraz dane historyczne. Nie zależą one natomiast od położenia obiektu, jego charakterystyki oraz stosowanych w zakładzie zabezpieczeń.

Przy opracowywaniu studiów uwarunkowań i kierunków zagospodarowania przestrzennego gminy zaleca się stosowanie tabeli klasyfikacyjnej, zawierającej wstępne 
odległości bezpieczne, w której uwzględniona została tylko ogólna klasyfikacja obiektu i rodzaj przemysłu. Przy opracowaniu miejscowych planów zagospodarowania przestrzennego zalecana jest tabela klasyfikacyjna, która zawiera szczegółowe wartości odległości bezpiecznych, a także w której uwzględnione zostały - poza rodzajem przemysłu - także rodzaj i ilość substancji niebezpiecznych oraz wielkość największego zbiornika na terenie zakładu.

W przypadku braku danych w tabelach dla danego zakładu lub potrzeby przeprowadzenia wnikliwszych analiz dopuszcza się stosowanie dodatkowych procedur w celu wyznaczenia odległości bezpiecznej. W procedurze tej do wyznaczenia zasięgów oddziaływania potencjalnych rodzajów awarii przemysłowych (stref zagrożenia wokół zakładów) wykorzystywane są modele matematyczne. Uwolnienia do powietrza substancji niebezpiecznych, do których dochodzi w większości awarii przemysłowych, wymagają zastosowania modeli rozprzestrzeniania się zanieczyszczeń w powietrzu atmosferycznym, w szczególności modeli rozprzestrzeniania się gazów cięższych od powietrza. Jest to praca dla eksperta. Przegląd modeli rozprzestrzeniania się zanieczyszczeń w powietrzu można znaleźć na przykład w pracach Markiewicz [33], [34], [35].

Należy podkreślić, że modeli tych jest bardzo dużo i nawet te najczęściej używane w zastosowaniach praktycznych istotnie różnią się między sobą pod względem szczegółowości opisów zjawisk związanych z rozprzestrzenianiem się zanieczyszczeń i wymagań co do danych wejściowych.

Podejścia dotyczące oceny ryzyka zagrożenia awarią przemysłową dla celów planistycznych są zróżnicowane w poszczególnych krajach Unii Europejskiej. Ocena ta może być realizowana $\mathrm{z}$ wykorzystaniem trzech rodzajów metod: metody deterministycznej tzn. z użyciem „najgorszego, możliwego scenariusza awarii” lub tabelarycznych odległości bezpiecznych, metody probabilistycznej tzn. oceny ilościowej ryzyka lub metody analizy wielokryterialnej [36-46]. Metoda z użyciem tabelarycznych odległości bezpiecznych - zalecana do stosowania w Polsce przy sporządzaniu opracowań planistycznych, opisana w Metodologii... - należy do metod najprostszych.

Dostosowanie regulacji krajowych do postanowień dyrektywy Seveso III jest realizowane Ustawą z dnia 23 lipca 2015 r. o zmianie Ustawy Prawo ochrony środowiska oraz niektórych innych ustaw [47]. Ustawa nowelizująca wprowadza przede wszystkim niezbędne przepisy do Ustawy z dnia 27 kwietnia 2001 r. Prawo ochrony środowiska [5] oraz szeregu rozporządzeń wykonawczych. Są one głównie w gestii ministra gospodarki i dotyczą: rodzajów i ilości substancji niebezpiecznych, których znajdowanie się w zakładzie decyduje o zaliczeniu go do zakładu o zwiększonym ryzyku albo zakładu o dużym ryzyku wystąpienia poważnej awarii przemysłowej [24]; wymagań, jakim powinien odpowiadać raport o bezpieczeństwie zakładu o dużym ryzyku [27]; wymagań, jakim powinny odpowiadać plany operacyjno-ratownicze [28]; szczegółowego zakresu informacji wymaganych do podania do publicznej wiadomości przez Komendanta Wojewódzkiego Państwowej
Straży Pożarnej [29]. Do Ustawy Prawo ochrony środowiska wprowadza się upoważnienie do wydania rozporządzenia, określającego kryteria ustalania bezpiecznych lokalizacji zakładów ZDR lub ZZR [48].

Poza wymienionymi wyżej aktami prawnymi nowelizacji wymagały: Ustawa z dnia 20 lipca 1991 r. o Inspekcji Ochrony Środowiska [20] oraz wydane na jej podstawie Rozporządzenie Ministra Środowiska z dnia 30 grudnia 2002 r. w sprawie poważnych awarii objętych obowiązkiem zgłoszenia do Głównego Inspektora Ochrony Środowiska [25]; Ustawa z dnia 27 marca 2003 r. o planowaniu i zagospodarowaniu przestrzennym [1]; Ustawa z dnia 3 października 2008 r. o udostępnianiu informacji o środowisku i jego ochronie, udziale społeczeństwa w ochronie środowiska oraz o ocenach oddziaływania na środowisko [4],Ustawa z dnia 24 sierpnia 1991 r. o Państwowej Straży Pożarnej [19] oraz wydane na jej podstawie Rozporządzenie Ministra Spraw Wewnętrznych i Administracji z dnia 24 października 2005 r. w sprawie czynności kontrolno-rozpoznawczych przeprowadzanych przez Państwową Straż Pożarną [31].

Proponowane przepisy dostosowują przede wszystkim istniejący system klasyfikacji zakładów ZDR lub ZZR do nowego systemu klasyfikacji substancji i mieszanin. Przyjęto, że prowadzący zakłady ZDR lub ZZR będą zobowiązani do wdrożenia programu zapobiegania poważnym awariom przemysłowym za pomocą systemu zarządzania bezpieczeństwem. System ten powinien zagwarantować odpowiedni w stosunku do zagrożeń poziom ochrony ludzi i środowiska. Wprowadzono ponadto obowiązek stałej aktualizacji tego programu. Ponadto uszczegółowiono zakres informacji, które musi uwzględniać dokumentacja opracowywana przez prowadzących zakłady o dużym i zwiększonym ryzyku wystąpienia poważnej awarii przemysłowej. Określono zasady i tryb przeprowadzenia kontroli (w tym wspólnych kontroli Państwowej Straży Pożarnej i Inspekcji Ochrony Środowiska) w zakładach ZDR i ZZR. Wzmocniono również wymogi dotyczące dostępu społeczeństwa do informacji o zagrożeniach poważnymi awariami.

Najważniejsze zmiany dotyczące zagadnień związanych z zagospodarowaniem przestrzennym obejmują: propozycję wydania nowego rozporządzenia przez ministra środowiska, w którym określone zostaną: sposób ustalania bezpiecznej odległości, rodzaje poważnych awarii przemysłowych, których potencjalne skutki należy uwzględnić przy ustalaniu takiej odległości, parametry graniczne oddziaływania potencjalnych skutków poważnych awarii przemysłowych oraz wprowadzenie konieczności uzgadniania decyzji lokalizacji inwestycji celu publicznego oraz decyzji o warunkach zabudowy z organami Inspekcji Środowiska i Państwowej Straży Pożarnej [49].

\section{Zakłady zagrożone ryzykiem poważnej awarii przemysłowej i sytuacja planistyczna w Poznaniu}

Zgodnie z Informacją o stanie bezpieczeństwa i ratownictwa miasta Poznania i powiatu poznańskiego za rok 2012 
[50], przygotowaną przez Komendę Miejską Państwowej Straży Pożarnej w Poznaniu, w mieście tym znajduje się 5 ZZR i 15 zakładów pozostałych, których działalność może spowodować wystąpienie poważnej awarii przemysłowej, nie funkcjonuje natomiast żaden zakład zaliczony do ZDR. Do ZZR należą:

1. Wyborowa S.A. - zakład znajduje się przy ulicy Janikowskiej, substancją niebezpieczną decydującą o zakwalifikowaniu do ZZR jest spirytus, przechowywany w zbiornikach magazynowych. Zakład jest na liście ZZR od $2002 \mathrm{r}$.

2. Kompania Piwowarska S.A. - zakład znajduje się przy ulicy Szwajcarskiej, substancją niebezpieczną decydującą o zakwalifikowaniu do ZZR jest amoniak, obecny $\mathrm{w}$ instalacjach chłodniczych. Zakład jest na liście ZZR od $2002 \mathrm{r}$.

3. ADOB Sp. z o.o. Sp.k. - zakład znajduje się przy ulicy Kołodzieja, substancjami niebezpiecznymi decydującymi o zakwalifikowaniu do ZZR są: kwas azotowy, jodan potasu, azotan potasu, nadtlenek wodoru, woda amoniakalna, jod, węglan miedzi, tlenek cynku oraz siarczan manganu, przechowywane w zbiornikach magazynowych, paletopojemnikach, a także w 25-kilogramowych workach. Zakład jest na liście ZZR od $2007 \mathrm{r}$.

4. HADEX GAZ Sp. z o.o. - zakład znajduje się przy ulicy Dąbrowskiego, substancją niebezpieczną decydującą o zakwalifikowaniu do ZZR jest propan-butan, znajdujący się w instalacjach technologicznych oraz przechowywany w zbiornikach magazynowych. Zakład jest na liście ZZR od $2009 \mathrm{r}$.

5. BROS Sp.j. - zakład znajduje się przy ulicy Karpia, substancją niebezpieczną decydującą o zakwalifikowaniu do ZZR jest propan-butan, znajdujący się w instalacjach technologicznych, zbiornikach magazynowych i opakowaniach jednostkowych na paletach zbiorczych. Zakład jest na liście ZZR od 2009 r.

Studium uwarunkowań i kierunków zagospodarowania przestrzennego miasta Poznania aktualizowane było kolejno w latach 2008 i 2012. Podjęta w 2012 r. aktualizacja studium, została zakończona uchwaleniem studium w roku 2014 [51]. W nowej wersji studium zagrożenie poważnymi awariami przemysłowymi poruszone jest w części omawiającej uwarunkowania rozwoju w podrozdziale 5.3 pt. „Uwarunkowania wynikające z zagrożenia bezpieczeństwa ludności i jej mienia”. Wymienione zostały zarówno zakłady ZZR występujące w mieście, jak i pozostałe zakłady będące potencjalnymi sprawcami poważnych awarii, ujęte w rejestrze Wojewódzkiego Inspektoratu Ochrony Środowiska. Podano, że maksymalny promień skażeń waha się od 0,8 do $3,5 \mathrm{~km}$. Dodatkowo podano, że w 14 podmiotach przechowywane są niebezpieczne substancje chemiczne, których szkodliwe oddziaływanie na ludzi może zaistnieć w promieniu do 1,6 km. Dalej czytamy: „Na terenie miasta Poznania w latach 2009-2012 nie odnotowano poważnych awarii przemysłowych, które wpłynęłyby w znaczący sposób na stan środowiska lub mogłyby stworzyć powszechne niebezpieczeństwo dla ludzi. Wystąpiło jedno zdarzenie o znamionach poważnych awarii w roku 2011" [51, s. 82].

W prognozie oddziaływania na środowisko do aktualizacji studium nie występuje tematyka zagrożenia awariami przemysłowymi [44].

Sytuacja planistyczna na obszarze Poznania jest bardzo dobra. Dane z dnia 30 listopada 2013 r. zawarte w uaktualnianej wersji studium potwierdzają, że w mieście obowiązuje 177 miejscowych planów, a kolejne 129 jest w opracowaniu. Pokrycie obszaru Poznania planami uchwalonymi wynosi $41 \%$, a sporządzanymi $27 \%$, co łącznie wynosi $68 \%$.

Obecnie obowiązujące miejscowe plany nie pokrywają obszarów, na których położone są zakłady Kompania Piwowarska S.A. i HADEX GAZ Sp. z o.o. Analizie poddane zostały zatem trzy wybrane miejscowe plany dla Poznania, na których położone są pozostałe trzy z pięciu zakładów ZZR.

\section{Analiza miejscowych planów zagospodarowania przestrzennego i prognoz oddziaływania na środowisko pod względem zapisów dotyczących zakładów przemysłowych stwarzających ryzyko wystąpienia poważnej awarii przemysłowej w Poznaniu}

Miejscowy plan zagospodarowania przestrzennego obszaru „Malta” uchwalony został 23 kwietnia 2002 r. [53]. Zakres planu obejmuje między innymi teren zakładu Wyborowa S.A. Teren zakładu ZZR na rycinie planu oznaczony został symbolem 6UT, czyli tereny usług rekreacyjnych (ryc. 1). Zgodnie z $\$ 9$ uchwały miejscowego planu, teren zakładu ma zostać przekształcony z obecnej funkcji na usługi rekreacyjno-sportowe. W tekście planu czytamy m.in.: „ustala się, w ciągu 15 lat od daty podjęcia niniejszej uchwały, przekształcenie terenu Zakładów Przemysłu Spirytusowego Wyborowa S.A. na tereny usług rekreacyjno-sportowych, oznaczone na rysunku planu symbolem 6UT” [53, s. 11]. Do czasu uzyskania docelowego przeznaczenia plan zezwala na obecne zagospodarowanie. Ogranicza możliwość rozbudowy i modernizacji istniejących budynków, nakazując także likwidację tymczasowych budynków gospodarczych oraz wiat. Wskazuje również na konieczność odnowienia elewacji budynków istniejących. W miejscowym planie nie pojawiają się zapisy dotyczące zagrożenia wystąpieniem poważnej awarii przemysłowej, nie zostały także wskazane odległości bezpieczne. 


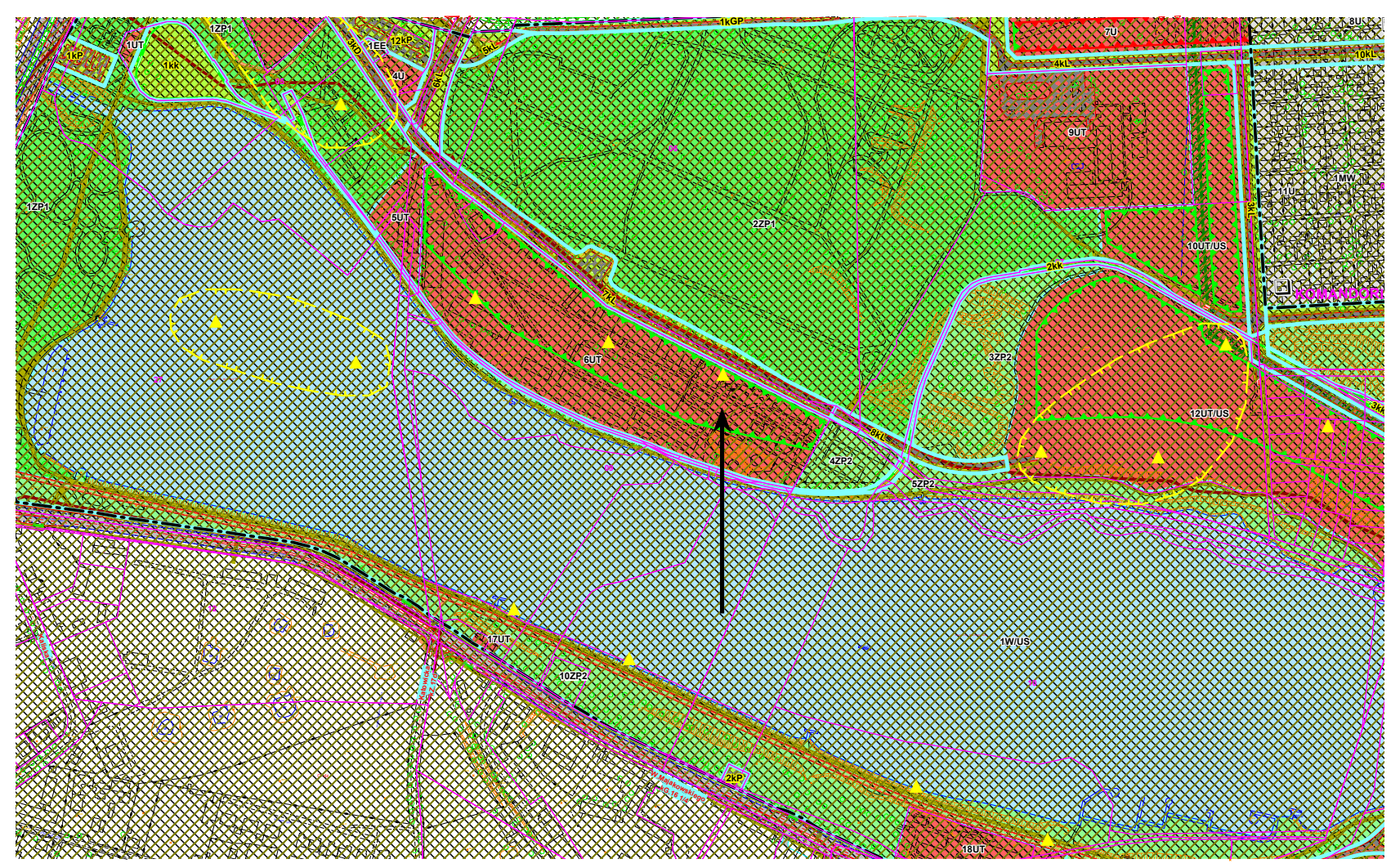

Ryc. 1. Fragment rysunku miejscowego planu zagospodarowania przestrzennego obszaru „Malta” w Poznaniu.

Lokalizację zakładu ZZR Wyborowa S.A. zaznaczono strzałką. Oryginalny rysunek planu jest sporządzony w skali 1:4000, jednak zamieszczony fragment planu nie zachowuje skali.

Legenda: wody powierzchniowe, zieleń urządzona, usługi

Fig. 1. A fragment of the map showing the area management plan for "Malta" district in Poznań. The location of the lower risk category establishment "Wyborowa" S.A. is shown by an arrow. The original map of the area management plan is drawn using a scale of 1:4000 however, the fragment of the map in the illustration does not correspond to the scale.

Legend: surface water, green belt area, commercial area

Źródło: Opracowanie własne na podstawie [53].

Source: Own elaboration adapted from [53].

Prognozę do miejscowego planu zagospodarowania przestrzennego obszaru „Malta” sporządzono w $2000 \mathrm{r}$. [54]. W odniesieniu do zakładu Wyborowa S.A. używana w niej jest dawna nazwa Poznańskie Zakłady Spirytusowe „Polmos”. Wzmianki o zakładzie znajdują się w części tekstowej w rozdziałach 3, 4 i 5. W rozdziale 3 pt. „Aktualny stan środowiska i uwarunkowania przyrodnicze do planu” Czytamy m.in.: „Obecnie na terenach objętych MPZP znajdują się: (...) obiekty aktywności gospodarczej m.in. Poznańskie Zakłady Spirytusowe - «Polmos»" [54, s. 7]. W rozdziale 4 pt. „Ocena stanu środowiska przyrodniczego, warunków do rekreacji, wypoczynku i życia człowieka na obszarze planu miejscowego »Malta« w Poznaniu” czytamy m.in.: „(...) w obrębie planu potencjalnym źródłem degradacji środowiska mogą być stacje paliw i magazyny »Polmosu «" [54, s. 20]. W rozdziale 5 pt. „Prognoza skutków wpływu ustaleń planu na środowisko" znajdują się m.in. zapisy: „W porównaniu z dotychczasowym zagospodarowaniem nowy plan: (...) docelowo ustala zamianę terenów aktywności gospodarczej (Zakłady Przemysłu Spirytusowego "Polmos« i baza techniczna Zarządu Zieleni Miejskiej przy ul. Świętojańskiej) na tereny usług rekreacyjnych, turystycznych i hotelowych" [54, s. 24] i „Ustalając docelowo w ciągu 10 lat likwidację Zakładów Spirytusowych »Polmos« i przekształcenie zajmowanych przez niego terenów na tereny usług turystycznych, plan likwiduje jedyny na jego obszarze teren aktywności gospodarczej, nie mieszczący się $\mathrm{w}$ funkcjach przewidywanych dla terenów zielonych $[54$, s. 30]".

W tekście prognozy brak jest jakichkolwiek informacji o zaliczeniu zakładu do ZZR i zagrożeniu poważną awaria przemysłową. Zakład stał się ZZR w 2002 r. Również w tym roku uchwalono miejscowy plan. Prawdopodobnie było to przed zaliczeniem zakładu do ZZR. W prognozie występuje pewna niezgodność znajdujących się tam zapisów z zapisami planu. Uży to innej nazwy zakładu i podano inny termin zamknięcia. Rysunek prognozy był niedostępny.

Miejscowy plan zagospodarowania przestrzennego obszaru „Janikowo 1” został przyjęty uchwałą z dnia 4 listopada 2008 r. [55]. W zakres obszaru planu wchodzi teren zakładu ADOB Sp. z o.o. Sp.k. (ryc. 2). Teren ZZR wchodzi w skład obszaru oznaczonego na rysunku planu symbolem P, czyli terenów zabudowy techniczno-produkcyjnej. W uchwale miejscowego planu brak jest zapisów dotyczących istniejącego ZZR. W bliskiej odległości, przy oddzieleniu drogą lokalną, przebiega linia zabudowy dla terenów usług z dopuszczeniem zabudowy mieszkaniowej jednorodzinnej. 


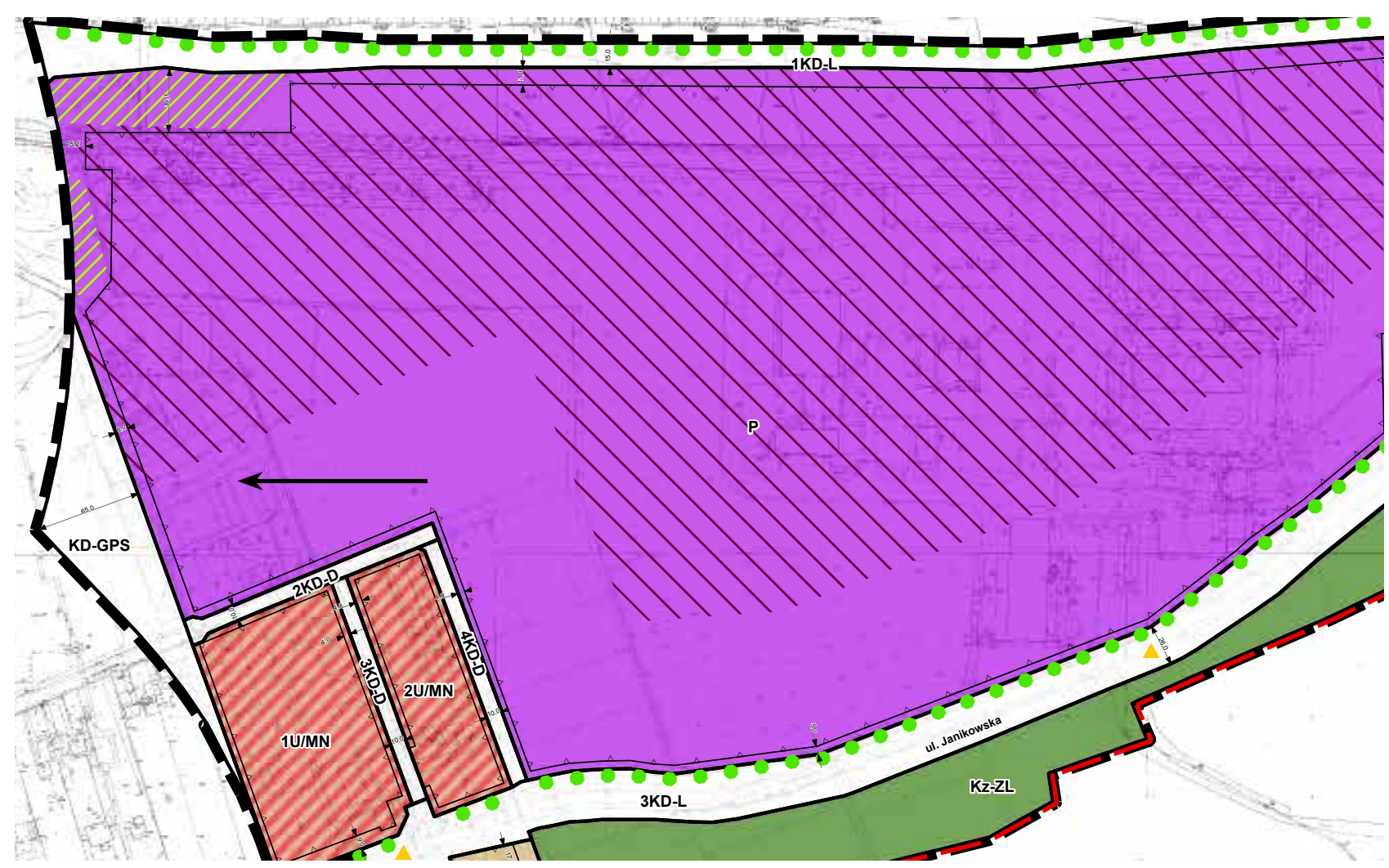

Ryc. 2. Fragment rysunku miejscowego planu zagospodarowania przestrzennego obszaru „Janikowo 1” w Poznaniu. Lokalizację zakładu ZZR ADOB Sp. z o.o. Sp.k. zaznaczono strzałką. Oryginalny rysunek planu jest sporządzony w skali 1:2000, jednak zamieszczony fragment planu nie zachowuje skali.

Legenda: przemysł, usługi/zabudowa mieszkaniowa jednorodzinna, zieleń naturalna

Fig. 2. A fragment of the map showing the area management plan for "Janikowo 1" district in Poznań. The location of the lower risk category establishment ADOB Sp. Z o.o. Sp.k. is shown by an arrow. The original map of the area management plan is drawn using a scale of 1:2000 however, the fragment of the map in the illustration does not correspond to the scale. Legend: industry, 12 commercial/housing area, green belt area

Źródło: Opracowanie własne na podstawie [55].

Source: Own elaboration adapted from [55].

Prognoza została wykonana w 2008 r. [56]. Wzmianki o zakładzie ADOB SP z o.o. znajdują się w rozdziałach 4 i 5. $\mathrm{W}$ rozdziale 4 pt. „Charakterystyka stanu funkcjonowania środowiska” czytamy m.in.: „Układ funkcjonalno-przestrzenny badanego obszaru rozdzielony jest ulicą Janikowską. Na północ od tej ulicy znajdują się tereny przemysłowe oraz usługowo-produkcyjne, w tym jeden $\mathrm{z}$ większych zakładów w Poznaniu - zakłady przemysłu spirytusowego Wyborowa S.A. oraz przedsiębiorstwo produkujące nawozy azotowe ADOB. (...) Istnieje niebezpieczeństwo wystąpienia poważnej awarii, co może mieć duże skutki i nieść niebezpieczeństwo skażenia środowiska, a przez to być niebezpieczne dla pracowników i mieszkańców tego obszaru. Istniejący zakład produkcyjny ADOB, wytwarzający m.in. płynne nawozy azotowe, $z$ uwagi na technologię produkcji został zakwalifikowany jako przedsięwzięcie mogące znacząco oddziaływać na środowisko. (...) Zakład ten został zaliczony do zakładów zwiększonego ryzyka wystąpienia awarii i zgłoszony do Komendy Miejskiej Straży Pożarnej. (...) Podsumowując, środowisko na analizowanym obszarze jest w dużym stopniu zagrożone, wymagane są różne działania zabezpieczające obszar objęty planem, zwłaszcza poprzez wyznaczenie nieprzekraczalnej granicy dla terenów przemysłowych, tak aby w jak największym stopniu ograniczyć ich negatywny wpływ na środowisko, a jednocześnie umożliwić funkcjonowanie i rozwój w ramach wyznaczonego obszaru" [55, s. 13]. W rozdziale 5 pt. „Ocena rozwiązań funkcjonalno-przestrzennych zawartych w projekcie planu miejscowego” czytamy m.in.: „Realizacja zabudowy produkcyjnej w planie skutkuje potencjalnymi zagrożeniami dla środowiska i może wpłynąć na warunki życia i zdrowia ludzi. Z drugiej strony ustalenia planu zapewniają kontrolowany rozwój zabudowy o funkcjach techniczno-produkcyjnych, zapewniają zachowanie terenów zieleni i w sposób odpowiedni wyznaczają granice zabudowy mieszkaniowej, tak aby nie dochodziło do konfliktów funkcjonalno-przestrzennych między poszczególnymi obszarami” [55, s. 13].

W tekście prognozy jest więc zarówno podana informacja o tym, że zakład ADOB należy do zakładów zwiększonego ryzyka zagrożenia poważną awarią, jak i informacja, że taka awaria może nieść niebezpieczeństwo dla ludzi i środowiska. Rysunek prognozy był niedostępny.

Miejscowy plan zagospodarowania przestrzennego obszaru „Naramowice - ul. Karpia” został uchwalony 7 kwietnia 2009 roku [57]. Do obszaru objętego planem 
wchodzi między innymi teren zakładu BROS Sp.j. (ryc. 3). Na rysunku został on oznaczony symbolem 1U/P, czyli tereny zabudowy usługowej oraz obiektów produkcyjnych, składów i magazynów. Zgodnie z $\$ 9$ uchwały miejscowego planu dla terenu zakładu, w celu ochrony terenów przyległych przewidziano nasadzenie pasa zieleni izolacyjnej.
W miejscowym planie nie pojawiają się zapisy dotyczące zagrożenia wystąpienia awarii przemysłowych, ani też nie wskazane zostały odległości bezpieczne. Poza strefą zieleni izolacyjnej, w miejscowym planie, nie ma żadnych ograniczeń dotyczących odległości, w jakiej może być lokalizowana zabudowa mieszkaniowa.

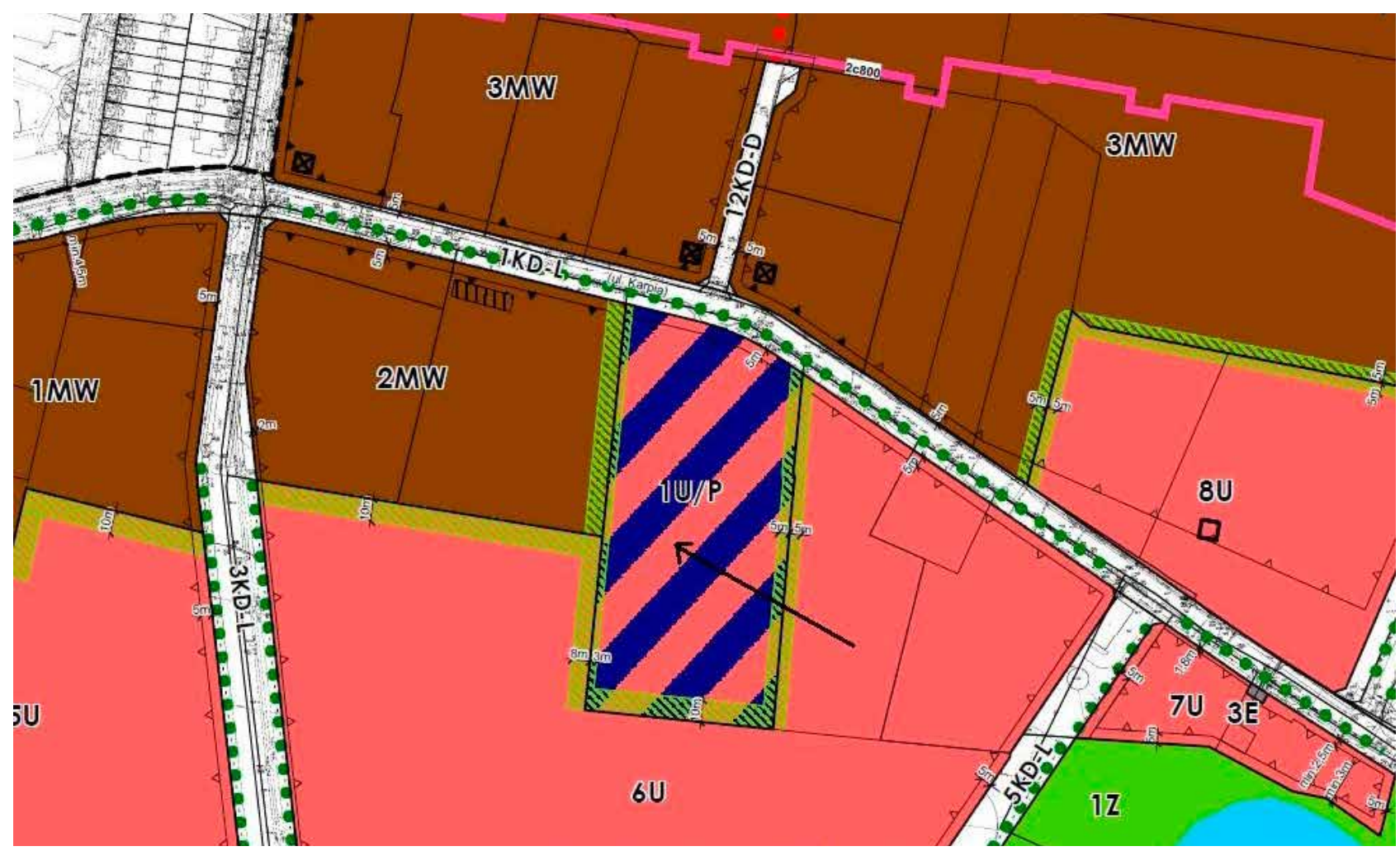

Ryc. 3. Fragment rysunku miejscowego planu zagospodarowania przestrzennego „Naramowice - ul. Karpia” w Poznaniu. Lokalizację zakładu ZZR BROS Sp.j. zaznaczono strzałką. Oryginalny rysunek planu jest sporządzony w skali 1:2000, jednak zamieszczony fragment planu nie zachowuje skali.

Legenda: _zabudowa mieszkaniowa wielorodzinna, usługi, _usługi/przemysł, _ zieleń urządzona, wody powierzchniowe.

Fig. 3. A fragment of the map showing the area management plan for "Naramowice - Karpia Street" district in Poznań. The location of the lower risk category establishment BROS Sp.j. is shown by an arrow. The original map of the local plan is drawn to a scale of 1:2000, however, the fragment of the map presented in the illustration does not correspond to the scale Legend: housing area, commercial area, commercial area/industry, green belt area, surface water Źródło: Opracowanie własne na podstawie [57].

Source: Own elaboration adapted from [57].

Prognoza do miejscowego planu zagospodarowania przestrzennego „Naramowice - ul. Karpia” powstała w 2008 r. [58]. Wzmianki o zakładzie BROS Sp. j. możemy przeczytać w rozdziałach 4 i 5 . W rozdziale 4 pt. „Charakterystyka poszczególnych elementów środowiska przyrodniczego i ich wzajemnych powiązań” czytamy m.in.: „Aktywność gospodarcza zlokalizowana została głównie wzdłuż ul. Karpia, a także przy ul. Dworskiej. Funkcja ta rozwinęła się tu zgodnie z zapisami nieobowiązującego miejscowego planu ogólnego miasta Poznania, który zakładał na tym terenie rozwój terenów aktywności gospodarczej - produkcji, dystrybucji towarów, handlu masowego, baz, składów, itp. W ramach tej funkcji powstały m.in. nowoczesne przedsiębiorstwa produkcyjno-usługowe i usługowe (m.in. Victus, Skotch, Talex S.A., BROS)" [58, s. 7]. W rozdziale 5 pt. „Ocena odporności środowiska na degradację i zdolności do regeneracji” czytamy m.in.: „Efektem trwających procesów adaptowania przedmiotowego terenu do celów działalności gospodarczej o funkcjach usługowych, magazynowych i przemysłowych jest postępujące zmniejszenie jego odporności na dalszą degradację" [58, s. 14].

W części tekstowej i na rysunku prognozy brak jest informacji o tym, że zakład BROS należy do zakładów ZZR $\mathrm{i}$ istnieje $\mathrm{z}$ jego strony zagrożenie awarią przemysłową, być może dlatego, że został on wprowadzony na listę ZZR już po uchwaleniu planu lub bardzo krótko przed tym. Zakład został wprowadzony na listę ZZR w 2009 r., podobnie jak plan, który został uchwalony w tym samym roku.

\section{Podsumowanie i wnioski}

Na podstawie przeglądu wybranych dokumentów planistycznych dla Poznania można sformułować następujące wnioski: 
1. W aktualizacji studium uwarunkowań i kierunków zagospodarowania przestrzennego Poznania podjętej w 2012 r. i zakończonej uchwaleniem w 2014 r. [51] znajduje się zarówno informacja o istniejących zakładach ZZR położonych na terenie Poznania, zagrożeniu awariami przemysłowymi, jak i o strefach zagrożenia. Natomiast w prognozie oddziaływania na środowisko [52] ten temat nie występuje.

2. Nie dla wszystkich obszarów zakładów o zwiększonym ryzyku zagrożenia awarią przemysłową znajdujących się na terenie Poznania zostały sporządzone miejscowe plany zagospodarowania przestrzennego. Tylko trzy spośród pięciu zakładów ZZR z Poznania objęte są miejscowymi planami zagospodarowania przestrzennego. Są to: Wyborowa S.A. - Miejscowy plan zagospodarowania przestrzennego obszaru „Malta” [55], ADOB Sp. z o.o. Sp.k. - Miejscowy plan zagospodarowania przestrzennego obszaru „Janikowo 1” [55], BROS Sp.j. - Miejscowy plan zagospodarowania przestrzennego obszaru „Naramowice - ul. Karpia” [57]. Można to wyjaśnić tym, że nie ma obowiązku sporządzania miejscowych planów dla obszarów, gdzie zlokalizowane są zakłady tego typu.

3. Nie we wszystkich miejscowych planach zagospodarowania przestrzennego lub prognozach oddziaływania na środowisko do planów, na obszarze których znajduje się zakład ZZR, zawarta jest informacja, że taki zakład jest zlokalizowany. Informacja o lokalizacji zakładu ZZR i zagrożeniu poważną awarią znajduje się tylko w jednym na trzy analizowane zestawy dokumentów planistycznych - dotyczy to prognozy do miejscowego planu obszaru „Janikowo 1" [56]. W dwóch pozostałych zestawach brak takich informacji. Można to próbować wyjaśnić, biorąc pod uwagę terminy: zgłoszenia zakładu jako ZZR, uchwalenia miejscowego planu wraz z prognozą, powstania obowiązku opiniowania projektu miejscowego planu pod względem zagrożenia poważnymi awariami przemysłowymi. Dwa analizowane plany najprawdopodobniej uchwalono przed zgłoszeniem zakładów jako ZZR. Tylko zakład ADOB Sp. z o.o. Sp.k. został zgłoszony jako ZZR przed uchwaleniem miejscowego planu „Janikowo 1" dla obszaru obejmującego teren zakładu. Wszystkie miejscowe plany uchwalone zostały przed wprowadzeniem obowiązku ich opiniowania pod względem zagrożenia poważnymi awariami przemysłowymi.

3. Wokół niewielu zakładów ZZR lub ZDR wprowadzony jest pas zieleni izolacyjnej. Tylko w przypadku jednego z trzech analizowanych miejscowych planów wprowadzono wokół terenu przemysłowego zabezpieczenie w postaci pasa zieleni, dotyczy to miejscowego planu dla obszaru „Naramowice - ul. Karpia” [57]. Obowiązku takiego nie ma.
4. Nie zaobserwowano, aby pojęcie odległości bezpiecznej było używane w praktyce planistycznej. W żadnym $\mathrm{z}$ analizowanych zestawów dokumentów planistycznych - miejscowym planie wraz z prognozą nie zostały wyznaczone odległości bezpieczne. W studium mówi się o strefach zagrożenia wokół zakładów, który to termin jest używany w specjalistycznych opracowaniach z zakresu oceny bezpieczeństwa w zakładach.

Podsumowując analizę wybranych dokumentów planistycznych, należy stwierdzić, że optymizmem nastrajają wyraźne zapisy - wprowadzone do aktualizacji studium z 2014 r. - o istniejących na terenie Poznania zakładach ZZR, strefach zagrożeń wokół nich i możliwościach wystąpienia poważnej awarii przemysłowej. Problematyka zagrożenia awariami przemysłowymi powoli „wkracza” do tych dokumentów. Zdaniem autorki pouczające byłoby rozszerzenie analiz na inne miasta i ponowne przeprowadzenie analiz dokumentów planistycznych dla Poznania za jakiś czas, tak aby dać możliwość powstania nowych dokumentów planistycznych po zmienionych regulacjach. Prace takie są już zaplanowane i mają objąć Warszawę, Kraków i Gdańsk. Dostosowanie regulacji krajowych do postanowień dyrektywy Seveso III jest realizowane Ustawą z dnia 23 lipca 2015 r. o zmianie Ustawy Prawo ochrony środowiska oraz niektórych innych ustaw [47]. Ustawa nowelizująca poza wprowadzeniem niezbędnych przepisów do Ustawy z dnia 27 kwietnia $2001 \mathrm{r}$. Prawo ochrony środowiska [5] (w tym zastąpieniem szeregu rozporządzeń do ustawy nowymi aktami wykonawczymi i dodanie jednego nowego rozporządzenia, określającego sposób ustalania bezpiecznej odległości przy lokalizacji zakładu stwarzającego zagrożenia wystąpienia poważnej awarii przemysłowej [48]) wprowadza również zmiany i uzupełnienia w ustawach: o Inspekcji Ochrony Środowiska [20]; o Państwowej Straży Pożarnej [19]; o planowaniu i zagospodarowaniu przestrzennym [1]; o udostępnianiu informacji o środowisku i jego ochronie; o udziale społeczeństwa w ochronie środowiska oraz o ocenach oddziaływania na środowisko [4]. Zdaniem autorki jest to bardzo pozytywna zmiana. Wydaje się, że warto byłoby się zastanowić nad rozszerzeniem Projektu rozporządzenia, który określiłby sposób definiowania odległości bezpiecznej przy lokalizacji zakładu stwarzającego zagrożenia wystąpienia poważnej awarii przemysłowej i wprowadzeniem do polskich regulacji referencyjnej metody obliczania zasięgów oddziaływania potencjalnych rodzajów poważnych awarii (modelu matematycznego).

Artykuł został opracowany w ramach pracy statutowej w Katedrze Ochrony i Kształtowania Środowiska na Wydziale Inżynierii Środowiska Politechniki Warszawskiej.

\section{Literatura}

[1] Ustawa z dnia 27 marca 2003 r. o planowaniu i zagospodarowaniu przestrzennym (Dz.U. z 2015 r., poz. 774).

[2] Rozporządzenie Ministra Infrastruktury z dnia 28 kwietnia 2004 r. w sprawie wymaganego zakresu projektu studium uwarunkowań i kierunków zagospodarowania przestrzennego (Dz.U. z 2004 r. nr 118, poz. 1233).

[3] Rozporządzenie Ministra Infrastruktury z dnia 26 sierpnia 2003 r. w sprawie wymaganego zakresu projektu miejscowego planu zagospodarowania przestrzennego (Dz. U. z 2003 r. nr 164, poz. 1587).

[4] Ustawa z dnia 3 października 2008 r. o udostępnianiu informacji o środowisku i jego ochronie, udziale 
społeczeństwa w ochronie środowiska oraz o ocenach oddziaływania na środowisko (Dz.U. z 2013 r., poz. 1235).

[5] Ustawa $z$ dnia 27 kwietnia 2001 r. Prawo ochrony środowiska (Dz. U. z 2015 r., poz. 933).

[6] Markiewicz M.T., Analiza wybranych opracowań planistycznych pod względem zagrożenia awariami przemysłowymi na przykładzie miasta Poznania. Praca statutowa, Katedra Ochrony i Środowiska, Politechnika Warszawska, Warszawa 2013.

[7] Konwencja Europejskiej Komisji Gospodarczej Organizacji Narodów Zjednoczonych (EKG ONZ) w sprawie transgranicznych skutków awarii przemysłowych sporządzona w Helsinkach dnia 18 marca $1992 \mathrm{r}$.

[8] Konwencja EKG ONZ o ocenach oddziaływania na środowisko w kontekście transgranicznym sporządzona w Espoo dnia 25 lutego $1991 \mathrm{r}$.

[9] Konwencja EKG ONZ o dostępie do informacji, udziale społeczeństwa w podejmowaniu decyzji oraz dostępie do sprawiedliwości w sprawach dotyczących środowiska, podpisana w Aarhus dnia 25 czerwca $1998 \mathrm{r}$.

[10] Dyrektywa Parlamentu Europejskiego i Rady 2012/18/UE z dnia 4 lipca 2012 r. w sprawie kontroli zagrożeń poważnymi awariami związanymi z substancjami niebezpiecznymi.

[11] Dyrektywa Rady 2003/35/WE z dnia 26 maja 2003 r. przewidująca udział społeczeństwa w odniesieniu do sporządzania niektórych planów i programów w zakresie środowiska oraz zmieniająca w odniesieniu do udziału społeczeństwa i dostępu do wymiaru sprawiedliwości Dyrektywy Rady 85/337/EWG i 96/61/WE.

[12] Dyrektywa Rady z dnia 27 czerwca 1985 r. 85/337/EWG w sprawie oceny skutków wywieranych przez przedsięwzięcia publiczne i prywatne na środowisko naturalne.

[13] Dyrektywa Rady 96/61/W z dnia 26 września 1996 r. dotycząca zintegrowanego zapobiegania zanieczyszczeniom i ich kontroli.

[14] Dyrektywa 2001/42/WE Parlamentu Europejskiego i Rady z dnia 27 czerwca 2001 r. w sprawie oceny wpływu niektórych planów i programów na środowisko.

[15] Dyrektywa Rady 96/82/WE z dnia 9 grudnia 1996 r. dotyczącą zarządzania poważnymi awariami przemysłowymi $\mathrm{z}$ udziałem substancji niebezpiecznych.

[16] Dyrektywa Parlamentu Europejskiego i Rady 2003/105/WE z dnia 16 grudnia 2003 r. nowelizująca zapisy Dyrektywy Rady 96/82/WE.

[17] Rozporządzenie Parlamentu Europejskiego i Rady (WE) nr 1272/2008 z dnia 16 grudnia 2008 r. w sprawie klasyfikacji, oznakowania i pakowania substancji i mieszanin, zmieniające i uchylające Dyrektywy 67/548/EWG] i 1999/45/WE oraz zmieniające rozporządzenie (WE) nr 1907/2006 (Dz. Urz. UE L 353 z 31.12.2008).

[18] Porównanie zapisów Dyrektywy Seveso II i Dyrektywy Seveso III [dok. elektr.] http://archiwum.CIOP.pl [dostęp wrzesień 2015].

[19] Ustawa z dnia 24 sierpnia 1991 r. o Państwowej Straży Pożarnej (Dz.U. 2015 r., poz. 881).

[20] Ustawa z dnia 20 lipca 1991 r. o Inspekcji Ochrony Środowiska (Dz.U. 2015 r., poz. 1223).

[21] Ustawa $\mathrm{z}$ dnia 16 kwietnia $2004 \mathrm{r}$ o ochronie przyrody (Dz. U. z 2015 r., poz. 1045).

[22] Ustawa z dnia 18 lipca 2001 r. Prawo wodne (Dz.U. z 2015 r., poz. 469).

[23] Małaczyński M., Bańkowska B., Wieszczeczyński T., Metodologia określania bezpiecznych lokalizacji zakładów mogacych powodować poważne awarie, GIOŚ, Warszawa 2007.

[24] Rozporządzenie Ministra Gospodarki z dnia 9 kwietnia 2002 r. w sprawie rodzajów i ilości substancji niebezpiecznych, których znajdowanie się w zakładzie decyduje o zaliczeniu go do zakładu o zwiększonym ryzyku albo zakładu o dużym ryzyku wystąpienia poważnej awarii przemysłowej (Dz.U. z 2002 r. nr 58, poz. 535).

[25] Rozporządzenie Ministra Środowiska z dnia 30 grudnia 2002 r. w sprawie poważnych awarii objętych obowiązkiem zgłoszenia do Głównego Inspektora Ochrony Środowiska (Dz.U. z 2002 r. nr 5, poz. 58).

[26] Bronisz B., Dadasiewicz P., Jastrzębska H., Raport o występowaniu zdarzeń o znamionach poważnej awarii, GIOŚ, Warszawa 2013.

[27] Rozporządzenie Ministra Gospodarki, Pracy i Polityki Społecznej z dnia 29 maja 2003 r. w sprawie wymagań, jakim powinien odpowiadać raport o bezpieczeństwie zakładu o dużym ryzyku (Dz.U. z 2003 r. nr 104, poz. 970).

[28] Rozporządzenie Ministra Gospodarki, Pracy i Polityki Społecznej z dnia 17 lipca 2003 r. w sprawie wymagań, jakim powinny odpowiadać plany operacyjno-ratownicze (Dz. U. 2003 r. nr 131, poz. 1219).

[29] Rozporządzenie Ministra Środowiska z dnia 4 czerwca 2002 r. w sprawie szczegółowego zakresu informacji wymaganych do podania do publicznej wiadomości przez komendanta wojewódzkiego Państwowej Straży Pożarnej (Dz.U. z 2002 r. nr 78, poz. 712).

[30] Rozporządzenie Ministra Ochrony Środowiska, Zasobów Naturalnych i Leśnictwa z dnia 29 marca 1995 r. w sprawie określenia wymagań jakim powinna odpowiadać prognoza skutków wpływu ustaleń miejscowego planu zagospodarowania przestrzennego na środowisko przyrodnicze (Dz. U. z 1995 r. nr 29, poz. 150).

[31] Rozporządzenie Ministra Spraw Wewnętrznych i Administracji z dnia 24 października 2005 r. w sprawie czynności kontrolno-rozpoznawczych przeprowadzanych przez Państwową Straż Pożarną (Dz.U. nr 225, poz. 1934).

[32] Małaczyński M., Bańkowska B., Wieszczeczyński T., Metodologia określania bezpiecznych lokalizacji zakładów mogacych powodować poważne awarie. Aktualizacja, GIOŚ, Warszawa 2010.

[33] Markiewicz M.T., A review of mathematical models for heavy gas dispersion in the atmosphere. Part I: Classification of models, "Chemistry and Ecological Engineering S", Vol. 19 Issue 3, 2012, pp. 297-314, doi: 10.2478/v10216-011-0022-4.

[34] Markiewicz M., A review of models for the atmospheric dispersion of heavy gases. Part II: Model quality evaluation, "Chemistry and Ecological Engineering S", Vol. 20 Issue 4, 2013, pp. 763-785, doi: 10.2478/eces-2013-0053.

[35] Markiewicz M.T., Podstawy modelowania rozprzestrzeniania się zanieczyszczeń w powietrzu atmosferycznym, Oficyna Wydawnicza Politechniki Warszawskiej, Warszawa 2004.

[36] Christou M.D., Struckle M., Land use planning guidelines in the context of article 12 of the Seveso II Directive, JRC, Ispra 2006.

[37] Papazoglou L. A., Nivoliantiou Z.S., Bonanos G.S., Land use planning stemming from the implementation of the SEVESO II Directive in the EU, "Journal of Hazardous Materials", Vol. 61 Issue 3, 1998, pp. 345-353, PII S0 304-3894(98)00142-3.

[38] Christou M.D., Amendola A., Smeder M., The control of major accident hazards: The land-use planning issue, "Journal of Hazardous Materials", Vol. 65 Issue 1-2, 1999, pp. 151- 178, PII: S0304-3894(98)00261-1.

[39] Gronberg C. (ed.), Land use planning and chemical sites. Summary report Riso R-1234 EN, Riso, Roskilde 2000.

[40] Cozzani V., Bandini R., Basta C., Christou M.D., Application of land-use planning criteria for the control of major accident hazards: A case-study, "Journal of Hazardous Materials", Vol. A136, 2006, pp. 170-180. doi:10.1016/j.hazmat.2005.12.031. 
[41] Basta C., Struckle S.M., Christou M., Land use planning in selected member states. Report EUR 23519 EN, IPSC, JRC, Ispra 2008.

[42] Basta C., Neuvel J.M.M., Zlatanova S., Ale B., Risk maps informing local use planning process. A survey on the Netherlands and the United Kingdom, "Journal of Hazardous Materials", Vol. 145, 2007, pp. 241-149, doi: 10.1016/j. Jhazmat.2006.11.032.

[43] Taveau J., Risk assessment and land use planning regulations in France following the AZF disaster. Journal of Loss Prevention in the Process Industries, Vol. 23, Issue 6, 2010, pp. 813-823, doi:10.1016/j.jlp.2010.04.003.

[44] Christou M., Gyenes Z., Struckle M., Risk assessment in support to land use planning in Europe: towards more consistent decisions?, "Journal of Loss Prevention in the Process Industries”, Vol. 24 Issue. 3, 2011, pp. 219-226, doi: 10.1016/j.jlp.2010.10.001.

[45] Tugnoli A. Gyenes Z., Wijk L.V., Christou M., Spandoni G., Cozzani V., Reference criteria for the identification of accident scenarios in the framework of land use planning, "Journal of Loss Prevention in the Process Industries", Vol. 26, 2013, pp. 614-627, http://dx.doi.org/10.1016/j.jpl.2012.12.004.

[46] Basta C., Sitting risky facilities: probabilism, determinism and beyond, "Planning theory", Vol. 13 Issue 1, 2014 pp. 44-46.

[47] Ustawa z dnia 23 lipca 2015 r o zmianie ustawy Prawo ochrony środowiska oraz niektórych innych ustaw (Dz.U. z 2015 r., poz. 1434).

[48] Projekt rozporządzenia, określającego kryteria ustalania bezpiecznych lokalizacji zakładów o dużym lub zwiększonym ryzyku wystąpieniu poważnej awarii przemysłowej.

[49] Projekt ustawy o zmianie ustawy Prawo ochrony środowiska oraz niektórych innych ustaw. Komentarz. [dok. elektr.] https://www.premier.gov.pl/wydarzenia/aktualności [dostęp: wrzesień 2015].

[50] Rewers W., Informacja o stanie bezpieczeństwa i ratownictwa miasta Poznania i powiatu poznańskiego za rok 2011, Komenda Miejska Państwowej Straży Pożarnej w Poznaniu, Poznań 2012.

[51] Studium uwarunkowań i kierunków zagospodarowania przestrzennego miasta Poznania. Aktualizacja z 2012 r., Poznań 2014, [dok. elektr.] http://www.mpu.poznan [dostęp: marzec 2014].

[52] Prognoza oddziaływania na środowisko do aktualizacji studium uwarunkowań i kierunków zagospodarowania przestrzennego miasta Poznania z 2012 r., Poznań 2014, [dok. elektr.] http://www.mpu.poznan [dostęp: marzec 2014].

[53] Miejscowy plan zagospodarowania przestrzennego obszaru „Malta”, Poznań, 2002, [dok. elektr.] http://www.mpu. poznan [dostęp: marzec 2014].

[54] Prognoza oddziaływania na środowisko do miejscowego planu zagospodarowania przestrzennego obszaru „Malta”, Poznań, 2000.

[55] Miejscowy plan zagospodarowania przestrzennego obszaru „Janikowo 1", Poznań, 2008 [dok. elektr.] http://www.mpu. poznan [dostęp: marzec 2014].

[56] Prognoza oddziaływania na środowisko do miejscowego planu zagospodarowania przestrzennego obszaru „Janikowo 1", Poznań, 2008.

[57] Miejscowy plan zagospodarowania przestrzennego obszaru „Naramowice - ul. Karpia”, Poznań 2009, [dok. elektr.] http://www.mpu.poznan [dostęp marzec 2014].

[58] Prognoza oddziaływania na środowisko do miejscowego planu zagospodarowania przestrzennego obszaru „Naramowice- ul. Karpia”, Poznań 2008.

dr inż. Maria Markiewicz - adiunkt w Katedrze Ochrony i Kształtowania Środowiska na Wydziale Inżynierii Środowiska Politechniki Warszawskiej. Obszary zainteresowań naukowych: ochrona powietrza, planowanie przestrzenne. 